\title{
Oceanic sources of continental precipitation and the correlation with sea surface temperature
}

\author{
Rudi J. van der Ent $^{1}$ and Hubert H. G. Savenije ${ }^{1}$ \\ Received 30 October 2012; revised 1 May 2013; accepted 2 May 2013; published 8 July 2013.
}

[1] Identifying the sources of continental precipitation has received increasing attention in recent years. With the use of various numerical methods, sources of precipitation have been identified from local to global scales. In this paper we identify the oceanic sources based on an atmospheric backtracking analysis of continental precipitation. We find that the strongest source areas are located close to the continents. In general, we define an oceanic area as a significant source when on average more than $20 \%$ of the total evaporation, and at least 250 $\mathrm{mm} / \mathrm{yr}$ of evaporation ends up as continental precipitation. We grouped these identified source areas into 15 regions and performed a forward tracking analysis of oceanic evaporation. We identified the areas on the adjacent continents that receive this oceanic moisture and whether this is nearby or remote. Moreover, we showed how the oceanic sources vary over the year in time and space. Furthermore, we correlated sea surface temperatures (SSTs) in the 15 source regions and the Niño 3.4 region with precipitation on all continents. For South America, we found that the El Niño Southern Oscillation (altering wind patterns) has a larger effect on precipitation than local SSTs. For West Africa, however, we show that SST in the source regions is strongly correlated with precipitation in the rainy season. In Australia, both local SST and the Niño 3.4 region appear to have a big influence on precipitation. As such this research provides new insight in the oceanatmosphere-land coupling, which can be useful for studying seasonal weather predictions as well as climate change impact.

Citation: van der Ent, R. J., and H. H. G. Savenije (2013), Oceanic sources of continental precipitation and the correlation with sea surface temperature, Water Resour. Res., 49, 3993-4004, doi:10.1002/wrcr.20296.

\section{Introduction}

[2] Where does precipitation come from? This question is difficult to answer because the complex and energy intensive processes that bring moisture to a certain location and cause moisture to precipitate are highly heterogeneous in space and variable over time. However, this question is highly relevant for a wide range of disciplines in Earth sciences. It is of importance for seasonal weather forecasting [see, e.g., Dominguez et al., 2009; Tuinenburg et al., 2011; van den Hurk et al., 2012], land and water management [see, e.g., Bagley et al., 2012; Keys et al., 2012; Spracklen et al., 2012; Tuinenburg et al., 2012], as well as for our understanding of the role of the hydrologi-

\footnotetext{
Additional supporting information may be found in the online version of this article.

${ }^{1}$ Department of Water Management, Faculty of Civil Engineering and Geosciences, Delft University of Technology, Delft, Netherlands.

Corresponding author: R. J. van der Ent, Department of Water Management, Faculty of Civil Engineering and Geosciences, Delft University of Technology, PO Box 5048, NL-2600GA Delft, Netherlands. (r.j.vanderent@tudelft.nl)

cal cycle in our climate system [see, e.g., Dominguez and Kumar, 2008; Dirmeyer et al., 2009b; van den Hurk and van Meijgaard, 2009; Goessling and Reick, 2011; Durkee et al., 2012].

[3] An increasing number of studies have attempted to answer identify the origin of precipitation for different regions and time periods. Although different methods have been used, a great deal of studies make use of water particle tracking (backward or forward in time), which is in principle always based on the water balance of the atmosphere. Obviously, the results obtained were all subject to assumptions made and to the type and accuracy of the data used [see Gimeno et al., 2012 for a review], but this uncertainty cannot take away their main findings. For example, these studies found that most precipitation on land originates from oceans, but that land evaporation, especially from forests, plays an important role in sustaining precipitation downwind.

[4] Many of these atmospheric moisture tracking studies focused on a particular basin, country, or terrestrial region and identified the moisture sources or sinks for that region taking account of interannual or seasonal variability [e.g., Druyan and Koster, 1989; Numaguti, 1999; Yoshimura et al., 2004; Bosilovich and Chern, 2006; Nieto et al., 2006; Sodemann et al., 2008; Dominguez et al., 2009; Drumond et al., 2010; Gangoiti et al., 2011a, 2011b; Bagley et al., 
2012; Keys et al., 2012; Tuinenburg et al., 2012]. More global characterizations of moisture sources showed the import and export of water vapor between nations [Dirmeyer et al., 2009a], or the oceanic versus terrestrial contributions to continental precipitation [e.g., van der Ent et al., 2010; Goessling and Reick, 2011]

[5] Our own recent work [van der Ent et al., 2010; van der Ent and Savenije, 2011] showed that globally about $40 \%$ of the precipitation on land originates from continental rather than oceanic evaporation. The global maps in these articles highlight the continental regions that are important moisture suppliers and which regions are strongly dependent on continental moisture recycling. It was, for example, shown that a very large portion $(60 \%-100 \%)$ of the evaporation in the African and South American rainforest returns as precipitation on land, with length scales (average travel distances) of less than $2000 \mathrm{~km}$, thus sustaining the climate of these continents. Another striking conclusion was that precipitation in the greater part of China consists for about $80 \%$ of recycled moisture from the Eurasian continent.

[6] Despite the importance of moisture recycling over continents, most moisture that brings precipitation on land has its origin in the oceans. Not many atmospheric moisture tracking studies have explicitly looked at oceanic sources of continental precipitation. Stohl and James [2005] tracked water particles forward in time from all oceanic basins and concluded that there is a relatively large role for the smaller oceanic basins such as the Red Sea compared to the Pacific Ocean in contributing to continental precipitation. Schicker et al. [2010] showed that the Mediterranean Sea is an important moisture source for Southern Europe, Eastern Europe, the Middle East, and Africa north of the equator. Gimeno et al. [2010, 2011] explicitly searched for oceanic regions that are strong moisture suppliers for the continent. They selected these regions based on high evaporation surplus $(E-P \geq 750$ $\mathrm{mm} / \mathrm{yr}$ ). Subsequently, they performed a forward particle tracking from these oceanic regions in order to find out where on the continent oceanic evaporation comes down as precipitation. They concluded that continental areas characterized by monsoon regimes benefit from a large number of oceanic source regions, which indicates the complex nature of precipitation. Another conclusion was that the Northern Atlantic subtropical source region impacts the continents considerably more than the large Southern Indian and North Pacific source. It should be noted that these studies all made use of FLEXPART [Stohl et al., 2005], which has the disadvantage that it cannot evaporate and precipitate separately, but only the fluxes into or out of the tracked air mass [Stohl and James, 2005].

[7] The main goal of this paper is to identify the oceanic source regions of continental precipitation, worldwide. In contrast to the studies of Gimeno et al. [2010, 2011] we do not identify these regions based on evaporation surplus, but we backtrack continental precipitation from all terrestrial areas (excluding Antarctica) in time and identify oceanic source regions based on their actual evaporation contributions. From these identified regions we do a forward tracking of oceanic evaporation in order to locate the continental areas that are influenced by these oceanic sources, whereby we also pay attention to the seasonality of these signals.

[8] A logical next step is to look at sea surface temperature (SST) variations within these oceanic source regions and how it affects precipitation in the corresponding terrestrial sink regions on land. Even storms originating outside the identified source regions must feed on the atmospheric moisture coming from evaporation in the source regions, which is obviously affected by SST. In this paper we provide case studies for South America, West Africa, and Australia showing the potential of using the identified oceanic source regions. We explore whether the local SST or the El Niño Southern Oscillation (ENSO) is a more important driver for precipitation on land.

\section{Data and Methods}

\subsection{Water Accounting Model}

[9] In order to identify the oceanic sources of continental precipitation we make use of the water accounting model (WAM) [van der Ent et al., 2010; van der Ent and Savenije, 2011; Keys et al., 2012]. The meteorological input data for this model are taken from the publicly available ERA-Interim reanalysis [Berrisford et al., 2009; Dee et al., 2011]. Although there remain some quality issues, ERA-Interim performs much better in reproducing the hydrological cycle than ERA-40 [Trenberth et al., 2011] and even performs better in terms of water balance closure than the newest reanalysis products Modern Era Retrospective-Analysis for Research and Applications and Climate Forecast System Reanalysis [Lorenz and Kunstmann, 2012]. The data we use are on a $1.5^{\circ}$ latitude $\times 1.5^{\circ}$ longitude grid and cover the period of 1989-2010, but the results are presented for 1990-2009, because we use 1 year as model spin-up time for both the backward and forward tracking. We use three-hourly precipitation and evaporation, and additionally, six-hourly specific humidity, zonal and meridional wind speed at the lowest 24 pressure levels $(175-1000 \mathrm{hPa})$, and surface pressure in order to calculate the (vertically integrated) horizontal moisture fluxes and precipitable water [see van der Ent et $a l ., 2010]$. In order to maintain numerical stability all calculations are performed with a $0.5 \mathrm{~h}$ time step.

[10] The underlying principle for WAM is the atmospheric water balance:

$$
\frac{\partial S_{a}}{\partial t}+\frac{\partial\left(S_{a} u\right)}{\partial x}+\frac{\partial\left(S_{a} v\right)}{\partial y}=E-P \quad\left[L^{3} T^{-1}\right]
$$

where $S_{a}$ is atmospheric moisture storage, $u$ is the wind speed in the $x$ direction, $v$ is the wind speed in the $y$ direction, $E$ is evaporation, and $P$ is precipitation. This mass conservation principle can also be applied on water of a certain origin $\Omega$ (i.e., evaporated from $\Omega$ ):

$$
\frac{\partial S_{a \Omega}}{\partial t}+\frac{\partial\left(S_{a \Omega} u\right)}{\partial x}+\frac{\partial\left(S_{a \Omega} v\right)}{\partial y}=E_{\Omega}-P_{\Omega} \quad\left[L^{3} T^{-1}\right]
$$

where $S_{a_{-} \Omega}$ is the part of the atmospheric moisture storage that is of origin $\Omega, E_{\Omega}$ is the evaporation from $\Omega$, and $P_{\Omega}$ is the part of the precipitation that has its moisture origin in 


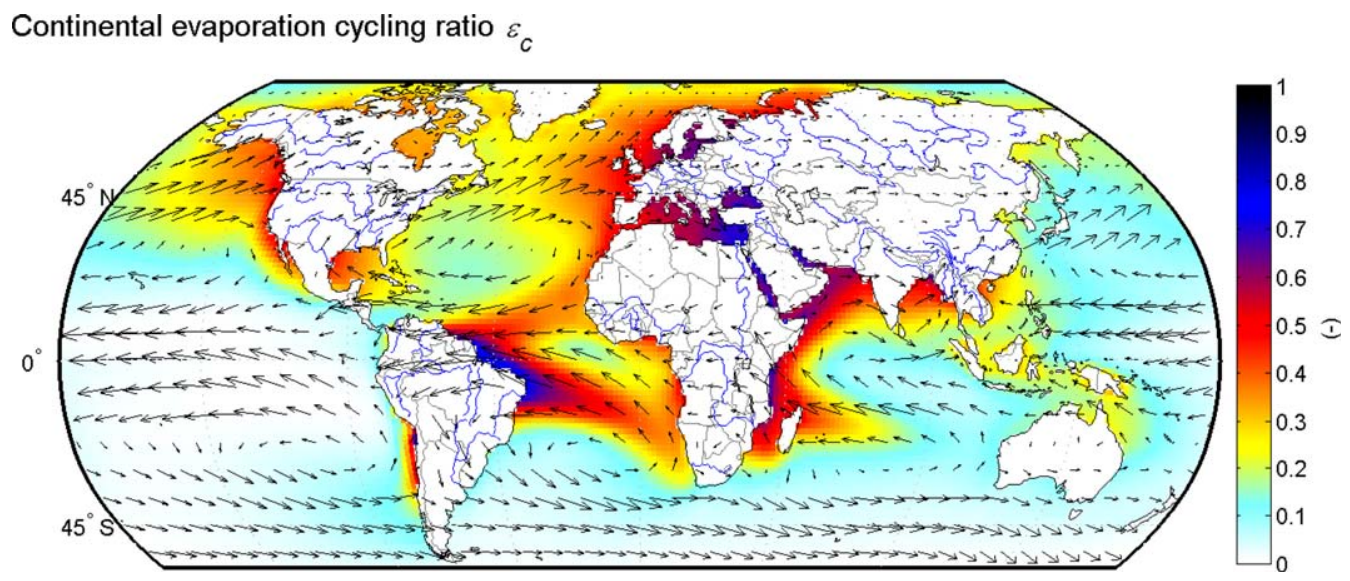

Figure 1. The continental evaporation cycling ratio $\varepsilon_{c}$ (equation (4)). This is the fraction of the evaporation that is transported to, and precipitates on, continents. These data are obtained from backward tracking the precipitation on the continents. The data are for the period 1990-2009 and displayed for oceanic regions only. See van der Ent et al. [2010] for the values on the continents themselves. The arrows indicate the horizontal moisture flux field.

$\Omega$. In our approach we assume that moisture in the atmosphere is well mixed, which implies that

$$
\frac{S_{a_{\Omega}}}{S_{a}}=\frac{\partial\left(S_{a \Omega} u\right) / \partial x}{\partial\left(S_{a} u\right) / \partial x}=\frac{\partial\left(S_{a \Omega} v\right) / \partial y}{\partial\left(S_{a} v\right) / \partial y}=\frac{P_{\Omega}}{P} .
$$

\subsection{Source Region Identification}

[11] In order to calculate how much evaporation a grid cell contributes to continental precipitation we used WAM to track continental precipitation backward in time. The results can be expressed as the continental evaporation cycling ratio $\varepsilon_{c}$ (Figure 1$)$ :

$$
\varepsilon_{c}(t, x, y)=\frac{E_{c}(t, x, y)}{E_{o}(t, x, y)+E_{c}(t, x, y)}=\frac{E_{c}(t, x, y)}{E(t, x, y)},
$$

where $E_{c}$ is evaporation that has a continental sink after transport through the atmosphere (i.e., precipitates on land rather than on the ocean), $E_{o}$ is the part of the evaporation that has an oceanic sink, and $E$ is total evaporation. We define an oceanic grid cell to be a significant source based on two criteria: more than $250 \mathrm{~mm} / \mathrm{yr}$ of evaporation is transported to a continental region $\left(E_{c} \geq 250 \mathrm{~mm} / \mathrm{yr}\right)$, and this is more than $20 \%$ of the total evaporation in that grid cell $\left(\varepsilon_{c} \geq 0.2\right)$. We group these grid cells into several larger source regions that can be seen as the major oceanic sources contributing to continental precipitation (Figure 2).

\subsection{Evaporationsheds}

[12] By applying forward tracking of evaporation from the oceanic source regions we identify the probabilistic spatial regions that rely on atmospheric moisture transport from evaporation in the oceanic source regions (Figures

Source regions

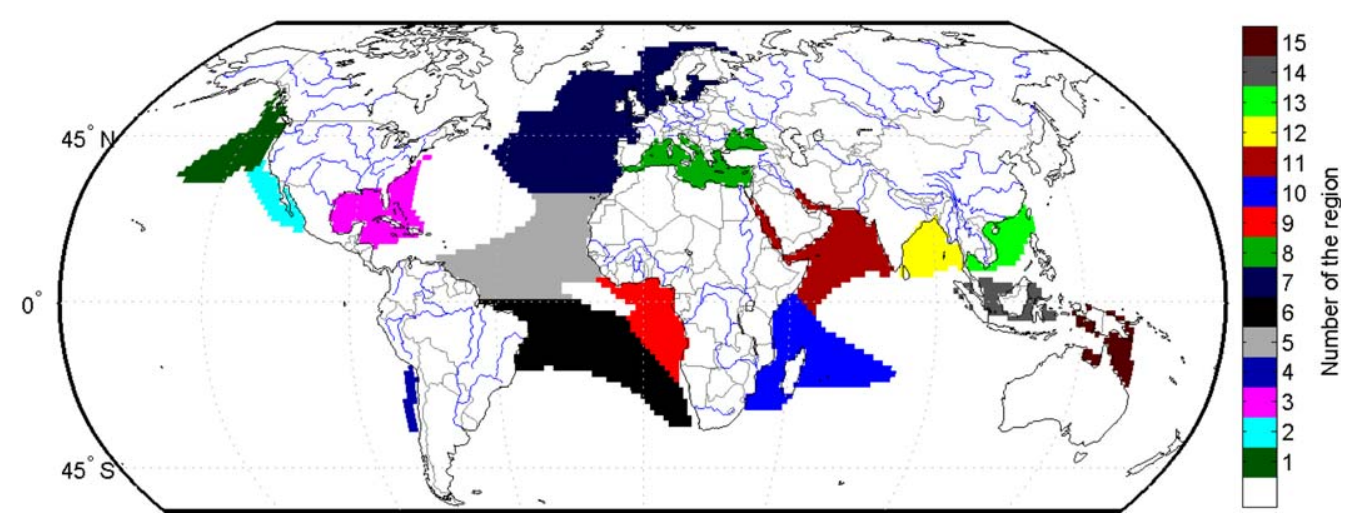

Figure 2. The 15 major oceanic source regions for continental precipitation, for the period 1990-2009. Each grid cell within a source region meets two criteria: more than $250 \mathrm{~mm} / \mathrm{yr}$ of evaporation is transported to a continental region $\left(E_{c} \geq 250 \mathrm{~mm} / \mathrm{yr}\right)$, and this is more than $20 \%$ of the total evaporation in that grid cell $\left(\varepsilon_{c} \geq 0.2\right.$, Figure 1 and equation (4)). 


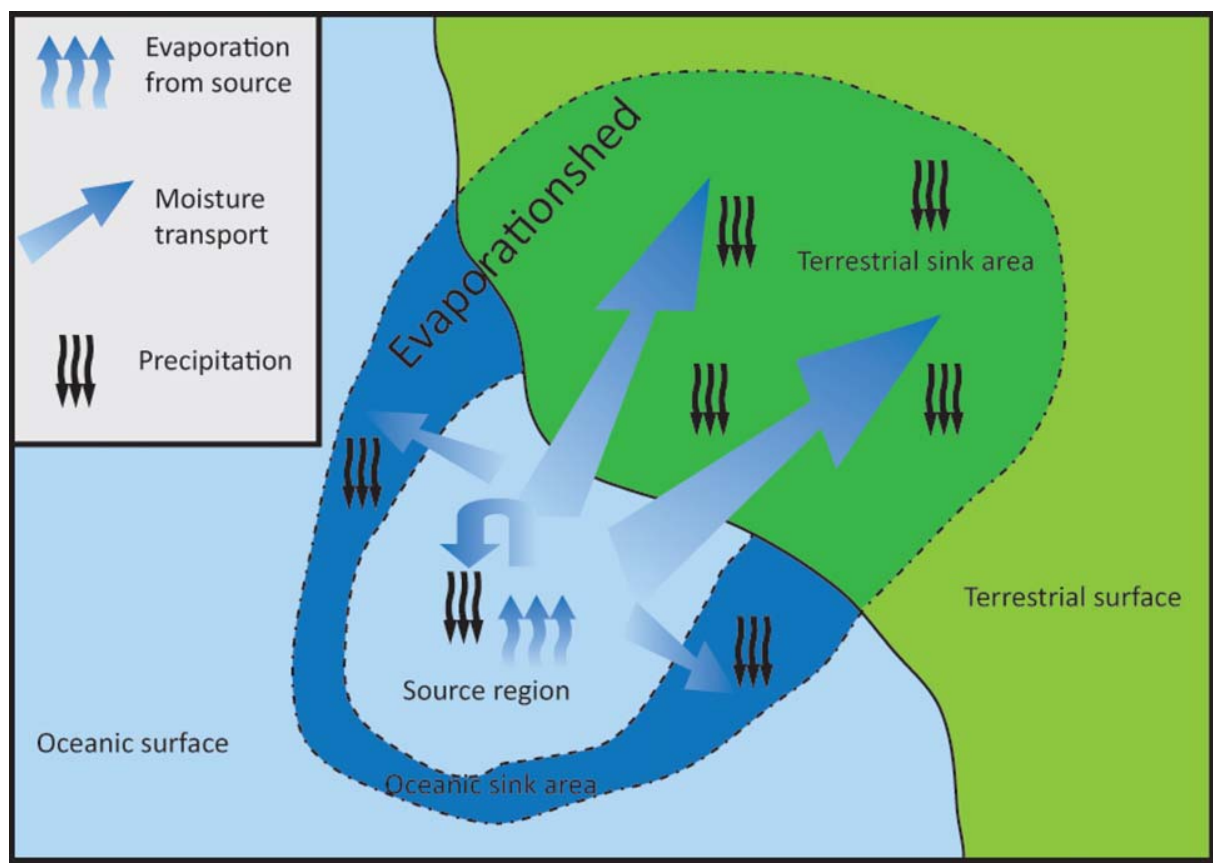

Figure 3. Conceptual image of an evaporationshed, with evaporation in the source region ending up on both terrestrial and oceanic sink regions as precipitation. Figure adapted from Keys et al. [2012].

S1-S15 in the supporting information). In other words, we find the evaporationsheds belonging to the source regions. Figure 3 shows a conceptual image of an evaporationshed. It is the opposite of a precipitationshed. Keys et al. [2012] defined a precipitationshed as the upwind oceanic or terrestrial surface that contributes moisture to a specific location's precipitation. Thus, an evaporationshed is the downwind oceanic or terrestrial surface that receives precipitation from a specific location's evaporation. It is important to realize that the actual boundary of an evaporationshed is not deterministic (as with a watershed) but probabilistic, although for visualization purposes it can be desirable to draw a single boundary. However, this requires a user-defined threshold of contribution to be chosen. The threshold value we choose for the boundary of each evaporationshed is based on relative contribution: we rank the grid cells by the fraction of precipitation received from a source region and proceed until the sum of these contributions to precipitation equals $50 \%$ of the evaporation in the source region (Figure 4).

\section{Evaporationsheds}

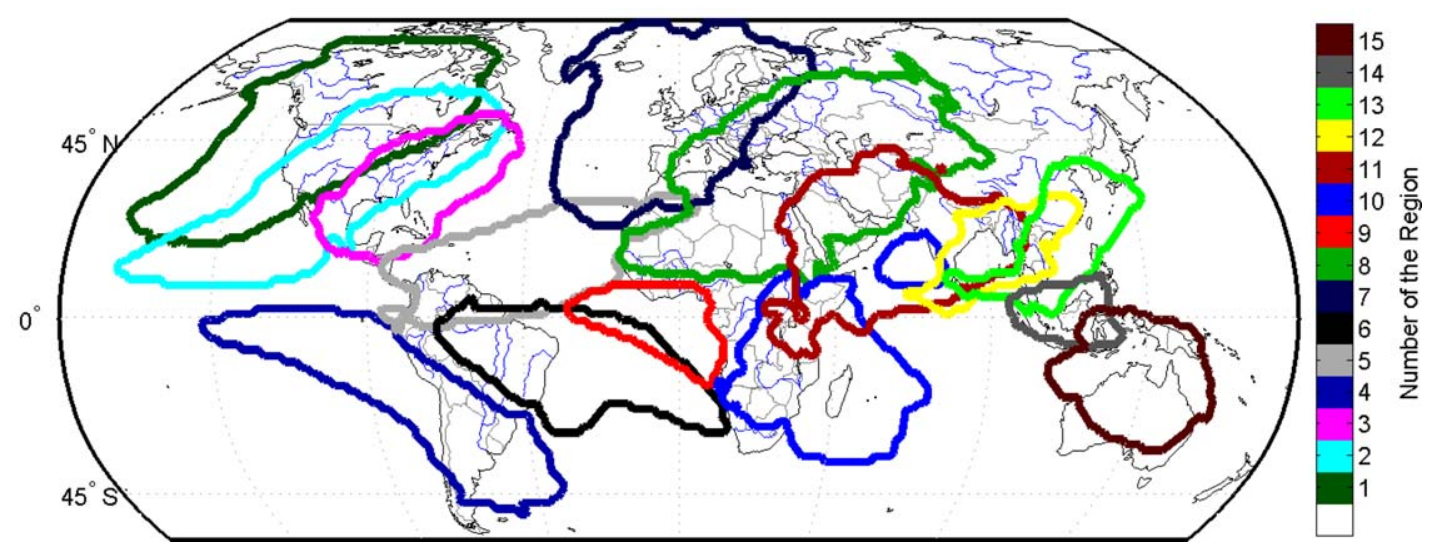

Figure 4. The 50\% evaporationsheds for the 15 corresponding oceanic source regions (Figure 2) for the period 1990-2009, obtained by forward tracking the evaporation from the source regions. The boundaries enclose the areas in which $50 \%$ of the evaporation from the corresponding source regions (Figure 2) ends up as precipitation. See Figures S1-S15 in the supporting information for more detailed evaporationsheds, and see section 2 on how the $50 \%$ boundaries have been obtained. 


\subsection{SST and Continental Precipitation}

[13] In order to further investigate the link between SST and continental precipitation, we did not use ERAInterim but used observational data sets instead. For SST we used $4 \mathrm{~km}$ AVHRR (advanced very high resolution radiometer) Pathfinder Version 5.1 data, obtained from the U.S. National Oceanographic Data Center (NODC/ NOAA) and GHRSST (http://pathfinder.nodc.noaa.gov) [Casey et al., 2010]. We used monthly values of the daytime observations of "first-guess SST" (Reynolds Optimally Interpolated SST, Version 2 product) from the Pathfinder algorithm, for the period 1982-2009. Furthermore, we used monthly $1.0^{\circ}$ gridded Global Precipitation Climatology Centre "full data reanalysis" version 6.0 precipitation [Becker et al., 2013; Schneider et al., 2011] for the same period. We calculated the Pearson correlation coefficients between monthly mean SST anomalies averaged over the various source regions and the Niño 3.4 (ENSO) region [see Trenberth, 1997], and the gridded monthly values of the precipitation data set with zero lag.

\section{Results}

\subsection{Oceanic Sources for Continental Precipitation}

[14] Figure 1 shows the mean spatial area of ocean surface that contributes to precipitation on the continents (according to equation (4)) as obtained from WAM (section 2.1). It shows that the strongest sources are found close to the continents. Based on WAM, we can say that the reason for this is simply that evaporation from oceanic regions further away from a land area mostly rains out on the oceans. However, depending on the direction and strength of the vertically integrated moisture flux (arrows) the extent of the source region can be much larger. This is, for example, the case for the two plumes from the Atlantic Ocean to South America, and for the North Atlantic Ocean to Europe. Surprisingly, some parts of the ocean, even if close to a continent, do not appear to be significant sources at all: e.g., the ocean near Argentina and Colombia, most of the ocean around Australia, and also the ocean near the Chinese coast. We also see that the eastern part of the Mediterranean, the Black sea, the Red sea, and the Arabian Gulf are very important source regions.

[15] Figure 2 shows the oceanic areas from which at least $20 \%$ of the evaporation goes to the continents, and where this is at least $250 \mathrm{~mm} / \mathrm{yr}$ (see equation (4)). These have been grouped into 15 large source regions. The white areas provide no substantial moisture contribution to the continents. Comparing the source regions (Figure 2) with those of Gimeno et al. [2010] we find that our results are considerably different. This is because we have based our criteria on the actual supply of water to the continents rather than the evaporation surplus. Gimeno et al. [2010] identified large sources in the Pacific Ocean (westward of South America) and the Indian Ocean (westward of Australia), which are in fact white areas that hardly provide moisture to continental precipitation, but their evaporated moisture apparently rains out before it reaches land, since otherwise these regions would have appeared as sources in our study (Figures 1 and 2). On the other hand, we here identify new oceanic sources: the Atlantic Ocean westward of Europe, the Bay of Bengal, and the South China Sea. Moreover, our source regions have a very different shapes (i.e., closer to the continents) compared with Gimeno et al. [2010].

[16] Figure 4 shows the boundaries of the regions where $50 \%$ of the evaporation from the corresponding source regions (Figure 2) ends up as precipitation. A more detailed evaporationshed for each of the regions in Figure 2 is shown in Figures $\mathrm{S} 1-\mathrm{S} 15$ in the supporting information. We can see that most of the oceanic regions transfer their evaporation to the adjacent continents following the direction of the horizontal moisture flux (see Figure 1). From the size of the evaporationsheds (Figure 4) compared to their source regions (Figure 2), it can be seen whether the moisture cycle is of local nature (regions 3,5 , 9 , and 14), associated with short length scales of moisture recycling [van der Ent and Savenije, 2011], or moisture is transported over greater distances (regions 1, 2, 4, 7, 8, $10,11,15)$.

[17] The continental areas that are not within any of the $50 \%$ evaporationsheds (Figure 4 ) receive their precipitation mostly from continental moisture sources (e.g., central South America, parts of West Africa, northern China, Mongolia, and eastern Siberia). Other regions (e.g., Patagonia, New Zealand, and the southern tips of Africa and Australia) receive most of their precipitation from minor oceanic sources that were not identified as major contributor regions in Figure 2. For other regions again, precipitation is a combination of minor oceanic sources and moisture recycling (e.g., several areas around the Arctic Ocean). Likewise, it is also possible that land areas within the $50 \%$ evaporationsheds receive most of their moisture from a terrestrial source. For a more global overview of the fraction of terrestrial evaporation in precipitation on continents we refer to van der Ent et al. [2010].

[18] It should be noted that these forward tracking results (Figure 4) are considerably different from those defined by Gimeno et al. [2010], even from similar regions (e.g., the Mediterranean Sea and the Caribbean Sea). This is partly due to the different methods used but also due to the different choice of boundaries. Our boundary choice provides information on the average travel length of an evaporated particle and whether the evaporated moisture returns locally or rather remotely (for more detail, see Figures S1b-S15b). On the other hand, the method of Gimeno et al. [2010] provides information on absolute contributions, as in Figures S1a-S15a, with the difference that our figures consider precipitation where Gimeno et al. [2010] consider the atmospheric moisture budget $E-P$.

\subsection{Seasonal Variations}

[19] Some of the regions in Figure 2 are constant sources of continental precipitation throughout the year, while others have a strong seasonal pattern. This can be seen from Figure 5, which shows the absolute contribution of evaporation to continental precipitation per month. The contributions of regions $3,6,8,10$, 


\section{Evaporation with continental sink $E_{c}$}
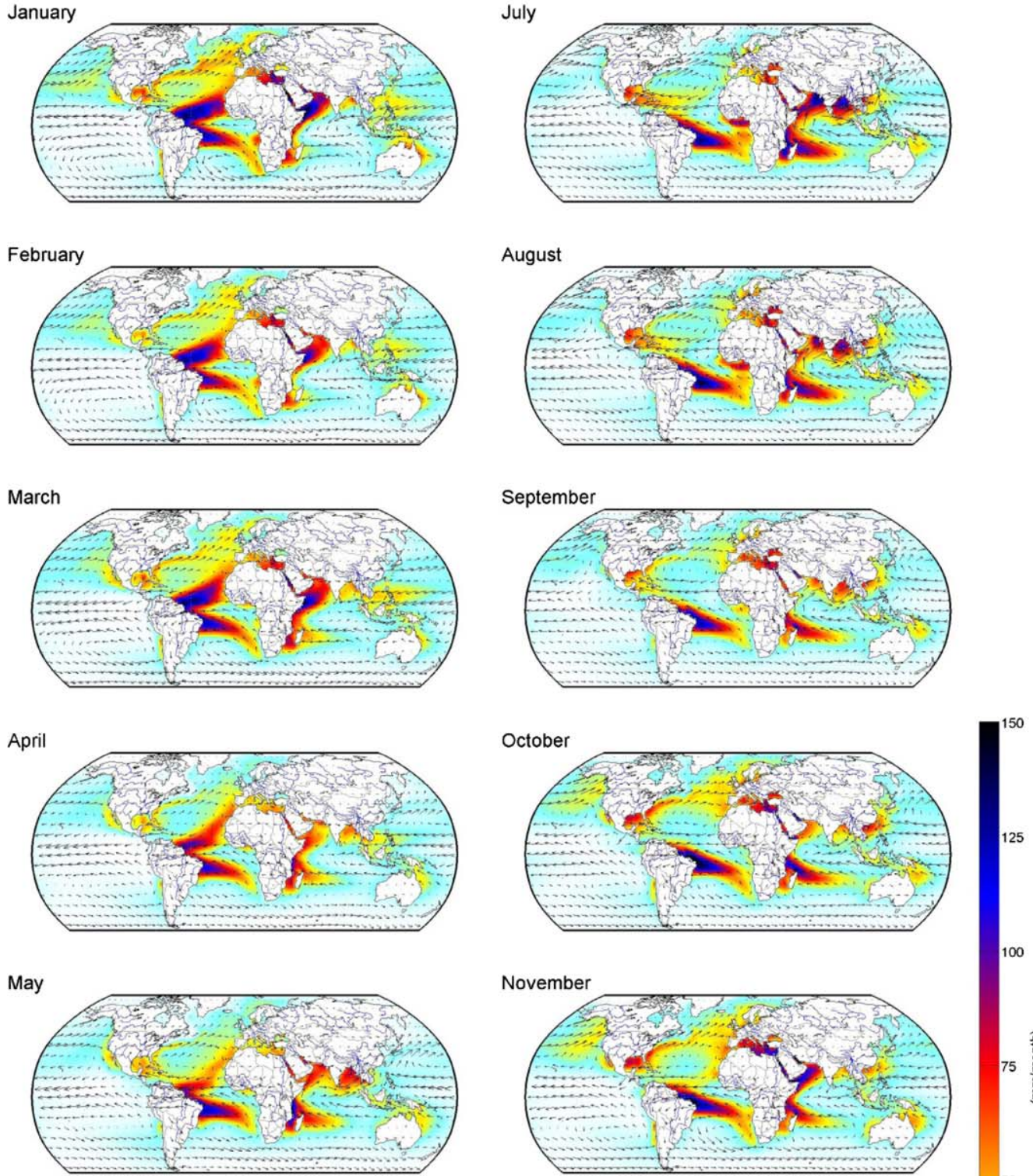

November
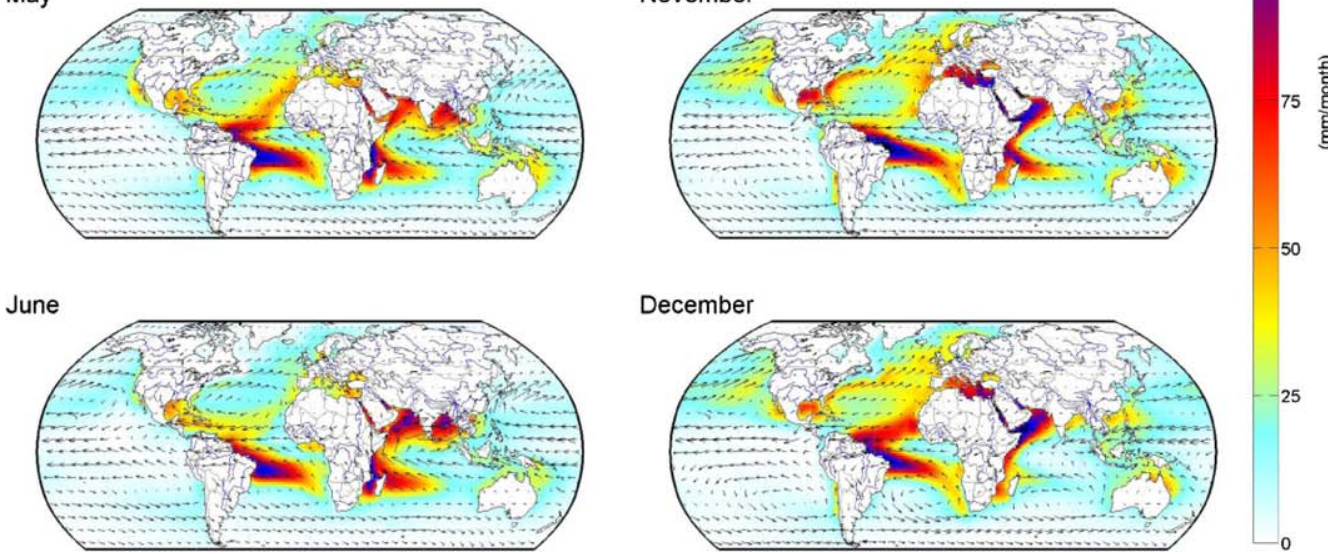

Figure 5. $E_{c}$ : the evaporation that has a continental sink after transport through the atmosphere (i.e., precipitates on land rather than on the ocean) displayed for each month. The data are for the period 1990-2009 and displayed for oceanic regions only. The arrows indicate the horizontal moisture flux field.

11,14 , and 15 are relatively constant throughout the year. However, the continental region receiving the moisture can vary. For region 10 we see that it supplies moisture to South Africa and Mozambique during December-March, with the moisture coming mainly from the Strait of Madagascar. During the rest of the year, region 10 remains an active source, but in that period most of the moisture is transported to the north in the direction of Kenya. In region 11 we note that it switches its moisture contribution between East 


\section{Correlation P and SST in Region 6 Correlation P and SST in Niño 3.4}
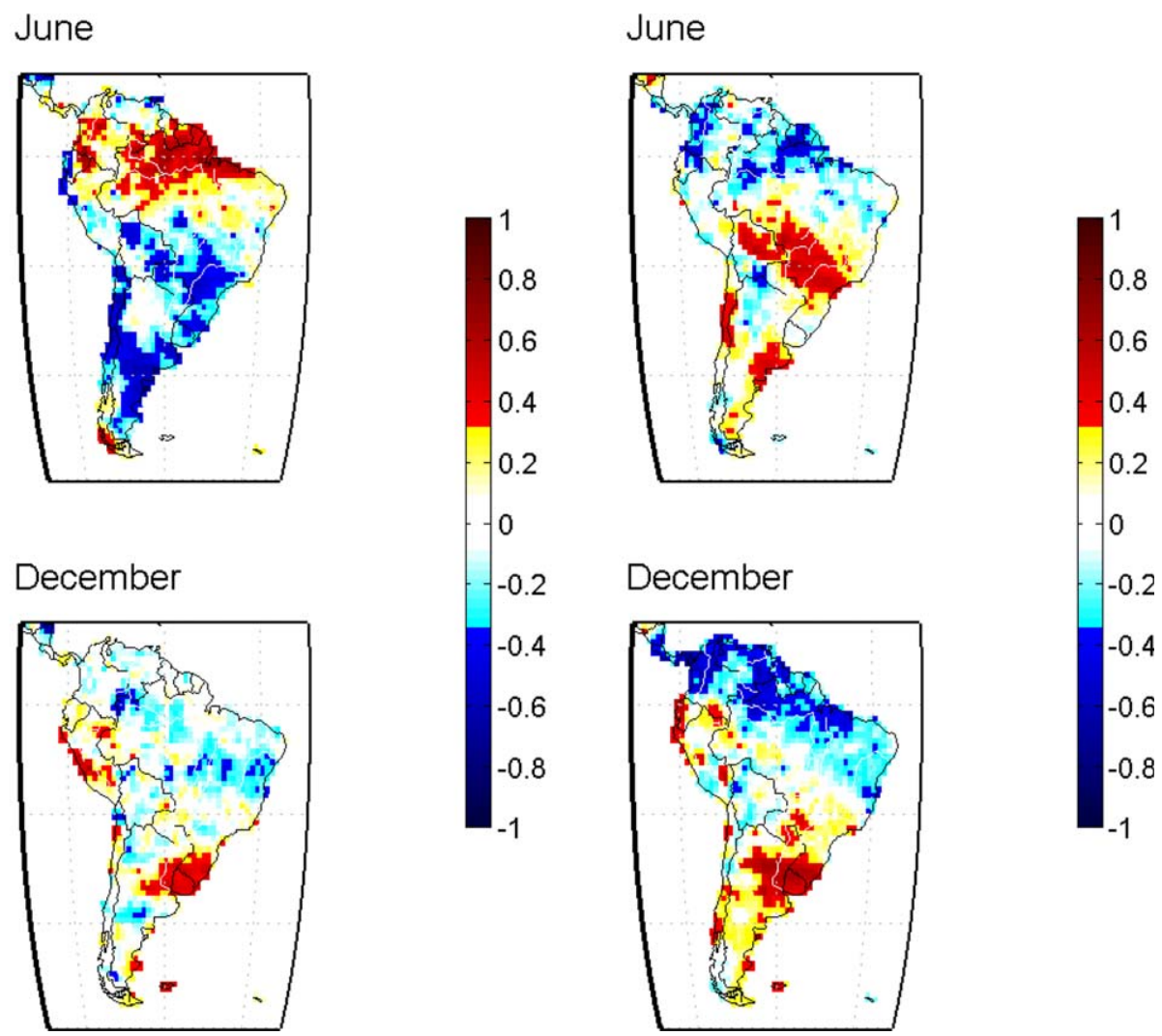

Figure 6. The correlation coefficient between GPCC precipitation in South America (SA) and SSTs for the period 1982-2009. The darker values are statistically significant ( $t$ test, $p=0.05$ ). (left) Correlation between precipitation in SA and the SST in region 6 (Figure 2). (right) Correlation between precipitation in SA and the SST in the Niño 3.4 region. See Figures S20-S23 in the supporting information for all months and all regions around SA.

Africa in October-April and India in May-September during the monsoon period.

[20] We also see that during May-September, region 12 (Bay of Bengal) becomes an important contributor to rainfall in Southeast Asia [see also, e.g., Tuinenburg et al., 2011]. The contribution of region 13 (South China Sea) peaks a bit later in August-November, when the contribution of region 12 is weakening and the monsoon period is in the declining phase. Likewise, region 9 (Gulf of Guinea) is clearly the source area of the West African monsoon during June-September [see also, e.g., Druyan and Koster, 1989; Hagos and Cook, 2007], although there is also a strong local moisture recycling component in West Africa during the rainy season [Savenije, 1995b, 1995a; Nieto et al., 2006; van der Ent and Savenije, 2011; Keys et al., 2012].

[21] Furthermore, regions 1, 2, and 7 in the North Pacific Ocean and North Atlantic Ocean (Figure 2) are more important for continental precipitation in October-March, when strong advection over the relatively warm oceans brings large quantities of water to the colder continents, which is largely contributed to the existence of atmospheric rivers [see, e.g., Dettinger et al., 2011]. During April-
September these oceanic source areas are weaker, and continental moisture recycling becomes important [see also, e.g., Bisselink and Dolman, 2008; Dominguez et al., 2009; van der Ent et al., 2010]. Two other regions with strong seasonal patterns are regions 4 and 5 (near South America), which only are significant moisture sources during November-May.

\subsection{Effect of SST in Oceanic Sources on Continental Precipitation}

[22] Many studies predict warmer seas and oceans due to increased greenhouse gas concentrations in the atmosphere [e.g., Xie et al., 2010]. It is well known that higher SSTs lead to more evaporation [Monteith, 1981] and more moisture present in the air above the sea due to the ClausiusClapeyron relation [Clausius, 1850]. All storms, even those originating outside actual oceanic source regions feed on moisture present in the atmosphere above the oceanic source regions. Therefore, higher SSTs in an oceanic source region (Figure 2) could possibly lead to increased precipitation on the adjacent continents (Figure 4).

[23] In this paper we explore the relation between SST and precipitation for all continents except Antarctica (see 
Correlation P and SST in Region 8

August

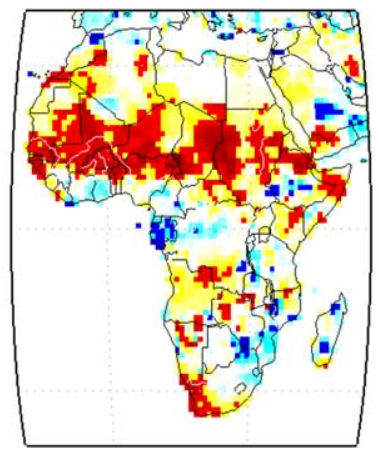

Correlation P and SST in Region 9

August

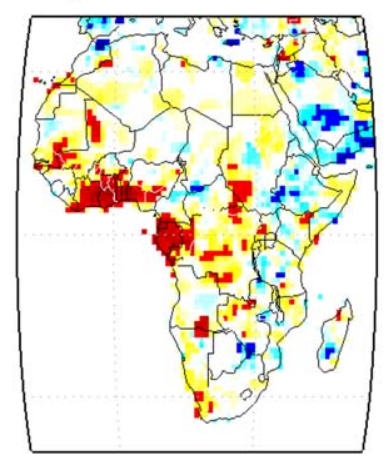

Correlation P and SST in Niño 3.4

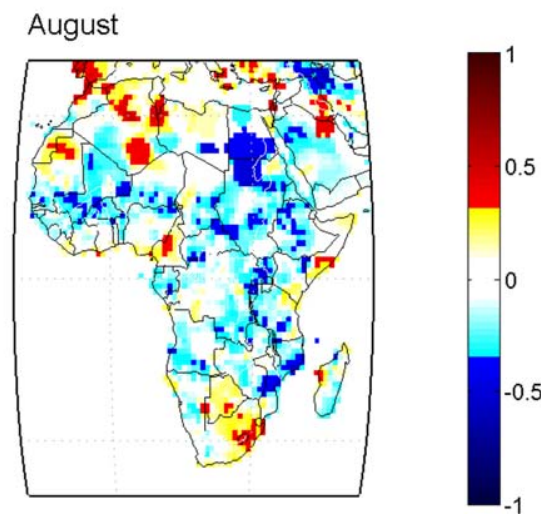

Figure 7. The correlation coefficient between GPCC precipitation in Africa and SSTs for the period 1982-2009. The darker values are statistically significant ( $t$ test, $p=0.05$ ). (left) Correlation between precipitation in Africa and the SST in region 8 (Figure 2). (middle) The same in region 9 (Figure 2). (right) Correlation between precipitation in SA and the SST in the Niño 3.4 region. See Figures S27-S31 in the supporting information for all months and all regions around Africa.

Figures S40 and S41 in the supporting information). We correlated monthly gridded precipitation on all continents with SST anomalies averaged over adjacent source regions (Figure 2) and the Niño 3.4 region [see Trenberth, 1997]. For all continents and months analyzed, see Figures S16S39 in the supporting information. These figures can be used as a reference for future research. Here however, we pick out three regions (South America, West Africa, and Australia) that we think are illustrative of how SST can affect rainfall and why the knowledge of oceanic source regions matters.

[24] The left part of Figure 6 shows the correlation of South American precipitation with SST in region 6 (tropical South Atlantic Ocean) for June and December (see Figure S22 for all months of the year). We identified region 6 as an important precipitation source for the eastern part of Brazil (Figure 3) [see also Drumond et al., 2010]. If positive anomalies in evaporation from region 6 indeed contrib- uted to more terrestrial precipitation, we would expect to see a positive correlation in each month, especially in the eastern part of Brazil. This, however, was hard to identify. We only found a positive correlation in the relatively dry months such as June (Figure 6). In general, there is no clear significant relationship between the SST in source region 6 and the precipitation on the adjacent continent.

[25] The right part of Figure 6 shows the correlation of South American precipitation with SST in the Niño 3.4 (ENSO) region for June and December (see Figure S23 for all months of the year). The correlation of precipitation with ENSO is a more coherent and clear pattern compared to the correlation pattern with region 6 . This suggests that ENSO and its associated changes in atmospheric circulation [Rahmstorf, 2002] are stronger linked to precipitation in South America [e.g., Chavasse and Seoane, 2009] than the more local effect of increased SSTs [see also Trenberth et al., 1998].

\section{Correlation P and SST in Region 15}

\section{November}

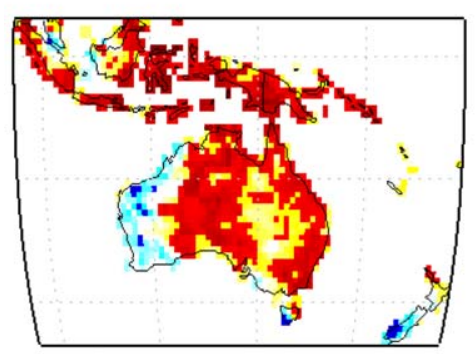

\section{Correlation P and SST in Niño 3.4}

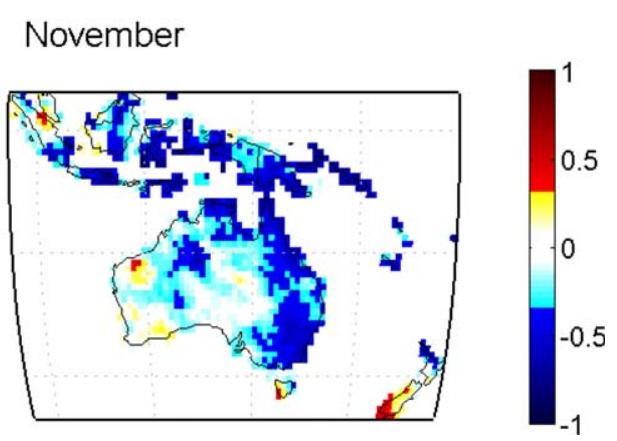

Figure 8. The correlation coefficient between GPCC precipitation in Oceania and SSTs for the period 1982-2009. The darker values are statistically significant ( $t$ test, $p=0.05$ ). (left) Correlation between precipitation in Oceania and the SST in region 15 (Figure 2). (right) Correlation between precipitation in Oceania and the SST in the Niño 3.4 region. See Figures S36-S38 in the supporting information for all months and all regions around Oceania. 
[26] Figure 7 shows the correlation of precipitation in Africa with SST in region 8 (Mediterranean Sea), region 9 (Gulf of Guinea), and the Niño 3.4 (ENSO) region for August. If we focus on West Africa, for which August is in the middle of the rainy season, we can see that the rainfall in the coastal region is strongly correlated with SST in the Gulf of Guinea, but the rainfall in the Sahel region is stronger correlated with SST in the Mediterranean Sea. ENSO, on the other hand, only has a weak (negative) correlation with precipitation. These results make sense from a precipitation sources point of view: the Sahel receives part of its rainfall from the Mediterranean but the coastal region much less (see Figure S8b) [also, e.g., Druyan and Koster, 1989; Nieto et al., 2006; Hagos and Cook, 2007; Schicker et al., 2010; Keys et al., 2011], although it has been speculated that part of the crossdesert transport of Mediterranean moisture into the Sahel could be an artifact of the moisture tracking models [Dirmeyer, 2011]. Nonetheless, these results are confirmed by previous observational and modeling studies that found similar relationships between SST and West African precipitation [e.g., Vizy and Cook, 2002; Rowell, 2003]. However, it should be noted that these correlation patterns are only present from July to October (Figures 7, S27, and S28).

[27] Figure 8 shows the correlation of precipitation in Oceania with SST in region 15 (Coral Sea) and the Niño 3.4 (ENSO) region for November. The same pattern (although less strong) can be seen throughout the whole year (Figures S37 and S38). It can be observed that local SST and ENSO have opposite effects. Based on Figures 8, S37, and S38 it can be hypothesized that a La Niña in combination with increased local SSTs can lead to major floods in eastern Australia, such as the 2010-2011 Queensland floods [Cai and van Rensch, 2012]. Interestingly, based on a regional climate modeling study, Evans and Boyer-Souchet [2012] arrived exactly at the same conclusion.

\subsection{Cautionary Notes}

[28] The oceanic source regions (Figure 2) and their corresponding evaporationsheds (Figure 4) have been established based on atmospheric moisture tracking with WAM using ERA-Interim data and thresholds that we defined. The results of this research could be somewhat different if performed with other models, data, or thresholds. Nonetheless, we do think that roughly the same 15 source regions would have been found, although their shape could be slightly different and their sizes could appear smaller or bigger. Unfortunately, isotopic studies [such as Henderson-Sellers et al., 2002; Yoshimura et al., 2003] that could quantitatively validate moisture tracking results at a global scale are still missing.

[29] The assumption of well-mixed horizontal moisture transport assumed here (equation (3)) may lead to inaccuracies particularly in the tropics [Goessling and Reick, 2012; van der Ent et al., 2013], possibly underestimating, for instance, the extent of source region 9 . The data itself also has an impact on the results; Trenberth et al. [2011] estimated a global overestimation of both precipitation and evaporation in the order of $10 \%$ over both the oceans and the land surface. In general, this would mean that the role of advection is slightly underestimated, and moisture travels further than what we see in Figures 5 and S1a-S15a. Figures 1 and 3 (and Figures S1b-S15b) are not expected to be so much affected, since they present relative numbers. Sensitivity tests with different data resolutions (not shown), however, had very little influence on the results.

[30] Considering the thresholds chosen in Figures 2 and 4 it should be noted that in each study in which moisture is tracked forward (or backward) from a certain region one needs to choose a threshold value when displaying the boundary of a moistureshed. This is always an arbitrary choice, and most studies have chosen it in terms of a certain flux but did not provide information on how much moisture the area within a boundary receives as a percentage of the source region's evaporation (forward tracking) or precipitation (backward tracking) [e.g., Sodemann et al., 2008; Dirmeyer et al., 2009a; Dominguez et al., 2009; Drumond et al., 2010; Gimeno et al., 2010]. We like to argue that this information is crucial in assessing the spatial extent of a source region's influence. When considering Figures S1-S15 without the second scale bar it is not possible to assess the travel distances of the atmospheric moisture. However, when the evaporationshed is simplified to only one boundary, as we did in Figures 3 and 4, there is a need for careful interpretation because much detailed information, such as provided in Figures S1-S15, is lost and another threshold choice would have altered the way the results are perceived.

[31] Regarding the correlation analysis between SSTs and terrestrial precipitation we must bear in mind that correlations cannot simply be thought of as causal relations. Figures S16-S39 in the supporting information should therefore be interpreted with caution and the local dynamics to be analyzed carefully before conclusions can be drawn. Even if strong positive correlations are found, this does not necessarily mean that there is a causal effect. It could, for example, also indicate that both local SST and land precipitation are increased by global warming, without the necessity of additional moisture transport from the oceanic region. Neither can we simply assume these correlations to remain static in time in view of the fact that these increased SSTs are predicted to increase heterogeneously over the globe [Xie et al., 2010], which may lead to changes in atmospheric circulation.

\section{Conclusions and Outlook}

[32] In this study we have investigated which oceanic regions act as sources for continental precipitation. We have distinguished 15 different regions which are all relatively close to the coasts. We found that whether a region is a source of continental precipitation or not depends on the prevalent wind directions rather than on the evaporation surplus (Figures 1 and 2). Forward tracking of evaporation from these sources has yielded a more detailed representation of which continental areas 
are most influenced by oceanic evaporation (Figures 4 and S1-S15).

[33] We found that several oceanic regions supply continental precipitation during the entire year, while others have a strong seasonal pattern (Figure 3). Interestingly, regions 1, 2, and 7 in the North Pacific Ocean and North Atlantic Ocean (Figure 2) were found to be relatively much more important during October-March, when the sea is warmer than the land. This indicates a more important role for land-atmosphere coupling during the summer season. For South America it was interesting to see how the contribution from region 5 (tropical North Atlantic Ocean) diminishes from June to October. The source regions around the Indian Ocean have the most complex behavior. They have varying receiver regions and are mostly activated during the monsoon.

[34] Analyzing the correlation of continental precipitation with SST (main effect: increasing evaporation) in the source regions versus ENSO (altering wind patterns), the following can be observed. For South America local SST seems to be of less influence than the ENSO effect. However, for West Africa there appears to be a clearer role for local SSTs. In Australia on the other hand, both a local SST and an ENSO effect can be discerned. In other parts of the world, that we did not analyze in detail, a wide range of SST effects on precipitation is expected: e.g., a role for local SSTs in Europe [e.g., Lenderink et al., 2009], ENSO effects in North America [e.g., McCabe and Dettinger, 1999], or more complicated dynamics during the Indian Monsoon [e.g., Li et al., 2001]. As a final point, we think that Figures S16-S39 in the supporting information can act as a starting point for future studies that wish to study the effect of local SST and ENSO on precipitation in more detail in their region of interest.

[35] Although the correlation maps (e.g., Figure 6 for South America) do not always show a clear correlation between local SST and continental precipitation, we think that the globally identified source regions still give important indications on the regions of interest for SSTprecipitation coupling. One of the difficulties is that a signal like ENSO and its associated changes in atmospheric circulation has not only a local but in fact a major global influence on precipitation [e.g., Trenberth et al., 1998; Ward et al., 2010; Lü et al., 2011]. The ENSO signal can outweigh the local SST signal, which actually makes the relationship between SSTs and continental precipitation nontrivial [e.g., Bichet et al., 2011]. However, Figures 7 and 8 also suggest that local SST may play an important role for continental precipitation.

[36] We feel that the accurate prediction of the effect of increasing SSTs, and the effect it has on continental precipitation, is a major challenge for future research [e.g., $M a$ and Xie, 2012; Trenberth and Fasullo, 2012]. But more importantly, it is very difficult to derive coping strategies on the basis of increasing SSTs or more frequent El Niño events. While the SSTs have increased in the past decades [Deser et al., 2010], the precipitation in the Amazon has actually decreased [Buarque et al., 2010]. This could very well be related to ongoing deforestation [Spracklen et al., 2012], which suggests that land use changes can outweigh the oceanic signal. Therefore, we feel that for the conserva- tion of future water resources it is vital to increase our knowledge on land-atmosphere feedbacks as well as oceanatmosphere feedbacks.

[37] Acknowledgments. This work is part of the research program Division for Earth and Life Sciences (ALW), which is financed by the Netherlands Organization for Scientific Research (NWO). We thank Patrick Keys (Stockholm Resilience Centre) for helpful comments on this manuscript. We also thank the Associate Editor and three anonymous reviewers for their constructive feedback.

\section{References}

Bagley, J. E., A. R. Desai, P. A. Dirmeyer, and J. A. Foley (2012), Effects of land cover change on moisture availability and potential crop yield in the world's breadbaskets, Environ. Res. Lett., 7(1), 014009, doi:10.1088/ 1748-9326/7/1/014009.

Becker, A., P. Finger, A. Meyer-Christoffer, B. Rudolf, K. Schamm, U. Schneider, and M. Ziese (2013), A description of the global land-surface precipitation data products of the Global Precipitation Climatology Centre with sample applications including centennial (trend) analysis from 1901-present, Earth System Science Data, 5(1), 71-99, doi: 10.5194/essd-5-71-2013.

Berrisford, P., D. Dee, K. Fielding, M. Fuentes, P. W. Kållberg, S. Kobayashi, and S. M. Uppala (2009), The ERA-Interim archive, ERA Rep. Ser., Eur. Cent. for Medium Range Weather Forecasts, Reading, U. K. [Available at http://www.ecmwf.int/research/era/do/get/era-interim.].

Bichet, A., M. Wild, D. Folini, and C. Schär (2011), Global precipitation response to changing forcings since 1870, Atmos. Chem. Phys., 11(18), 9961-9970, doi:10.5194/acp-11-9961-2011.

Bisselink, B., and A. J. Dolman (2008), Precipitation recycling: Moisture sources over Europe using ERA-40 data, J. Hydrometeorol., 9(5), 10731083, doi:10.1175/2008JHM962.1.

Bosilovich, M. G., and J. D. Chern (2006), Simulation of water sources and precipitation recycling for the MacKenzie, Mississippi, and Amazon River basins, J. Hydrometeorol., 7(3), 312-329, doi:10.1175/JHM501.1.

Buarque, D. C., R. T. Clarke, and C. A. B. Mendes (2010), Spatial correlation in precipitation trends in the Brazilian Amazon, J. Geophys. Res., 115, D12108, doi:10.1029/2009jd013329.

Cai, W., and P. van Rensch (2012), The 2011 southeast Queensland extreme summer rainfall: A confirmation of a negative Pacific Decadal Oscillation phase?, Geophys. Res. Lett., 39(8), L08702, doi:10.1029/ $2011 \mathrm{gl} 050820$.

Casey, K. S., T. B. Brandon, P. Cornillon, and R. Evans (2010), The past, present, and future of the AVHRR SST Program, in Oceanography from Space: Revisited, edited by V. Barale et al., Springer, Dordrecht.

Chavasse, D. I., and R. S. Seoane (2009), Assessing and predicting the impact of El Nino Southern Oscillation (ENSO) events on runoff from the Chopim River basin, Brazil, Hydrol. Processes, 23(22), 3261-3266, doi: $10.1002 /$ hyp. 7392 .

Clausius, R. (1850), Ueber die bewegende Kraft der Wärme und die Gesetze, welche sich daraus für die Wärmelehre selbst ableiten lassen [in German], Ann. Phys., 155(3), 368-397, doi:10.1002/andp.18501550306.

Dee, D. P., et al. (2011), The ERA-Interim reanalysis: Configuration and performance of the data assimilation system, Q. J. R. Meteorol. Soc., 137(656), 553-597, doi:10.1002/qj.828.

Deser, C., A. S. Phillips, and M. A. Alexander (2010), Twentieth century tropical sea surface temperature trends revisited, Geophys. Res. Lett., 37, L10701, doi:10.1029/2010g1043321.

Dettinger, M. D., F. M. Ralph, T. Das, P. J. Neiman, and D. R. Cayan (2011), Atmospheric rivers, floods and the water resources of California, Water, 3(2), 445-478.

Dirmeyer, P. (2011), Interactive comment on "Analyzing precipitationsheds to understand the vulnerability of rainfall dependent regions" by $P$. W. Keys et al., Biogeosci. Discuss., 8, C4544-C4546.

Dirmeyer, P. A., K. L. Brubaker, and T. DelSole (2009a), Import and export of atmospheric water vapor between nations, J. Hydrol., 365(1-2), 1122, doi:10.1016/j.jhydrol.2008.11.016.

Dirmeyer, P. A., C. A. Schlosser, and K. L. Brubaker (2009b), Precipitation, recycling, and land memory: An integrated analysis, J. Hydrometeorol., 10(1), 278-288.

Dominguez, F., and P. Kumar (2008), Precipitation recycling variability and ecoclimatological stability-A study using NARR Data. Part I: Central U.S. plains ecoregion, J. Clim., 21(20), 5165-5186, doi:10.1175/ 2008JCLI1756.1. 
Dominguez, F., J. C. Villegas, and D. D. Breshears (2009), Spatial extent of the North American Monsoon: Increased cross-regional linkages via atmospheric pathways, Geophys. Res. Lett., 36, L07401, doi:10.1029/ $2008 \mathrm{gl037012.}$

Drumond, A., R. Nieto, R. Trigo, T. Ambrizzi, E. Souza, and L. Gimeno (2010), A Lagrangian identification of the main sources of moisture affecting northeastern Brazil during its pre-rainy and rainy seasons, PLoS ONE, 5(6), e11205.

Druyan, L. M., and R. D. Koster (1989), Sources of Sahel precipitation for simulated drought and rainy seasons, J. Clim., 2, 1438-1446.

Durkee, J. D., L. Campbell, K. Berry, D. Jordan, G. Goodrich, R. Mahmood, and S. Foster (2012), A synoptic perspective of the record 1-2 May 2010 mid-south heavy precipitation event, Bull. Am. Meteorol. Soc. 93(5), 611-620, doi:10.1175/bams-d-11-00076.1.

Evans, J. P., and I. Boyer-Souchet (2012), Local sea surface temperatures add to extreme precipitation in northeast Australia during La Niña, Geophys. Res. Lett., 39, L10803, doi:10.1029/2012g1052014.

Gangoiti, G., I. Gómez-Domenech, E. Sáez de Cámara, L. Alonso, M. Navazo, J. Iza, J. A. García, J. L. Ilardia, and M. M. Millán (2011a), Origin of the water vapor responsible for the European extreme rainfalls of August 2002: 2. A new methodology to evaluate evaporative moisture sources, applied to the August 11-13 central European rainfall episode, J. Geophys. Res., 116, D21103, doi:10.1029/2010jd015538.

Gangoiti, G., E. Sáez de Cámara, L. Alonso, M. Navazo, M. C. Gómez, J. Iza, J. A. García, J. L. Ilardia, and M. M. Millán (2011b), Origin of the water vapor responsible for the European extreme rainfalls of August 2002: 1. High-resolution simulations and tracking of air masses, J. Geophys. Res., 116, D21102, doi:10.1029/2010jd015530.

Gimeno, L., A. Drumond, R. Nieto, R. M. Trigo, and A. Stohl (2010), On the origin of continental precipitation, Geophys. Res. Lett., 37, L13804, doi:10.1029/2010g1043712.

Gimeno, L., R. Nieto, A. Drumond, A. M. Durán-Quesada, A. Stohl, H. Sodemann, and R. M. Trigo (2011), A close look at oceanic sources of continental precipitation, Eos Trans. AGU, 92(23), 193-194, doi:10.1029/2011EO230001.

Gimeno, L., A. Stohl, R. M. Trigo, F. Dominguez, K. Yoshimura, L. Yu, A. Drumond, A. M. Durán-Quesada, and R. Nieto (2012), Oceanic and terrestrial sources of continental precipitation, Rev. Geophys., 50, RG4003, doi: 10.1029/2012RG000389.

Goessling, H. F., and C. H. Reick (2011), What do moisture recycling estimates tell us? Exploring the extreme case of non-evaporating continents Hydrol. Earth Syst. Sci., 15(10), 3217-3235, doi:10.5194/hess-15-32172011.

Goessling, H. F., and C. H. Reick (2012), Atmospheric water vapour tracers and the significance of the vertical dimension, Atmos. Chem Phys. Discuss., 12(11), 30,119-30,176, doi:10.5194/acpd-12-301192012.

Hagos, S. M., and K. H. Cook (2007), Dynamics of the West African monsoon jump, J. Clim., 20(21), 5264-5284, doi:10.1175/2007JCLI1533.1.

Henderson-Sellers, A., K. McGuffie, and H. Zhang (2002), Stable isotopes as validation tools for global climate model predictions of the impact of Amazonian deforestation, J. Clim., 15(18), 2664-2677, doi:10.1175/ 1520-0442(2002)015<2664:SIAVTF $>2.0$. CO\%3B2.

Keys, P. W., R. J. van der Ent, L. J. Gordon, H. Hoff, R. Nikoli, and H. H. G. Savenije (2011), Analyzing precipitationsheds to understand the vulnerability of rainfall dependent regions, Biogeosci. Discuss., 8(5), 10,487-10,516, doi:10.5194/bgd-8-10487-2011.

Keys, P. W., R. J. van der Ent, L. J. Gordon, H. Hoff, R. Nikoli, and H. H. G. Savenije (2012), Analyzing precipitationsheds to understand the vulnerability of rainfall dependent regions, Biogeosciences, 9(2), 733-746, doi: $10.5194 /$ bg-9-733-2012.

Lenderink, G., E. van Meijgaard, and F. Selten (2009), Intense coastal rainfall in the Netherlands in response to high sea surface temperatures: Analysis of the event of August 2006 from the perspective of a changing climate, Clim. Dyn., 32(1), 19-33, doi:10.1007/s00382-008-0366-x.

Li, T., Y. Zhang, C. P. Chang, and B. Wang (2001), On the relationship between Indian Ocean sea surface temperature and Asian Summer Monsoon, Geophys. Res. Lett., 28(14), 2843-2846, doi:10.1029/2000g1011847.

Lorenz, C., and H. Kunstmann (2012), The hydrological cycle in three state-of-the-art reanalyses: Intercomparison and performance analysis, $J$. Hydrometeorol., 13, 1397-1420, doi:10.1175/jhm-d-11-088.1.

Lü, A., S. Jia, W. Zhu, H. Yan, S. Duan, and Z. Yao (2011), El NiñoSouthern Oscillation and water resources in the headwaters region of the Yellow River: Links and potential for forecasting, Hydrol. Earth Syst. Sci., 15(4), 1273-1281, doi:10.5194/hess-15-1273-2011.
Ma, J., and S.-P. Xie (2012), Regional patterns of sea surface temperature change: A source of uncertainty in future projections of precipitation and atmospheric circulation, J. Clim., 26, 2482-2501, doi:10.1175/jcli-d-1200283.1 .

McCabe, G. J., and M. D. Dettinger (1999), Decadal variations in the strength of ENSO teleconnections with precipitation in the western United States, Int. J. Climat., 19(13), 1399-1410, doi:10.1002/ (sici)1097-0088(19991115)19:13<1399: :aid-joc457>3.0.co;2-a.

Monteith, J. L. (1981), Evaporation and surface temperature, Q. J. R. Meteorol. Soc., 107(451), 1-27, doi:10.1002/qj.49710745102.

Nieto, R., L. Gimeno, and R. M. Trigo (2006), A Lagrangian identification of major sources of Sahel moisture, Geophys. Res. Lett., 33(18), doi:10.1029/2006GL027232.

Numaguti, A. (1999), Origin and recycling processes of precipitating water over the Eurasian continent: Experiments using an atmospheric general circulation model, J. Geophys. Res., 104(D2), 1957-1972.

Rahmstorf, S. (2002), Ocean circulation and climate during the past 120,000 years, Nature, 419(6903), 207-214.

Rowell, D. P. (2003), The impact of Mediterranean SSTs on the Sahelian rainfall season, J. Clim., 16(5), 849-862, doi:10.1175/15200442(2003)016<0849:tiomso > 2.0.co;2.

Savenije, H. H. G. (1995a), Does moisture feedback affect rainfall significantly?, Phys. Chem. Earth, 20(5-6), 507-513.

Savenije, H. H. G. (1995b), New definitions for moisture recycling and the relationship with land-use changes in the Sahel, J. Hydrol., 167(1-4), 57-78.

Schicker, I., S. Radanovics, and P. Seibert (2010), Origin and transport of Mediterranean moisture and air, Atmos. Chem. Phys., 10(11), 50895105, doi:10.5194/acp-10-5089-2010.

Schneider, U., A. Becker, P. Finger, A. Meyer-Christoffer, B. Rudolf, and M. Ziese (2011), Monthly Land-Surface Precipitation from Rain-Gauges Built on GTS-Based and Historic Data, Global Precip. Climatol. Cent. (GPCC), Deutscher Wetterdienst, doi:10.5676/DWD_GPCC/ FD_M_V6_100. [Available at http://gpcc.dwd.de/.].

Sodemann, H., C. Schwierz, and H. Wernli (2008), Interannual variability of Greenland winter precipitation sources: Lagrangian moisture diagnostic and North Atlantic Oscillation influence, J. Geophys. Res., 113, D03107, doi:10.1029/2007jd008503.

Spracklen, D. V., S. R. Arnold, and C. M. Taylor (2012), Observations of increased tropical rainfall preceded by air passage over forests, Nature, 489, 282-285, doi:10.1038/nature 11390.

Stohl, A., and P. James (2005), A Lagrangian analysis of the atmospheric branch of the global water cycle. Part II: Moisture transports between earth's ocean basins and river catchments, J. Hydrometeorol., 6(6), 961984, doi:10.1175/JHM470.1.

Stohl, A., C. Forster, A. Frank, P. Seibert, and G. Wotawa (2005), Technical note: The Lagrangian particle dispersion model FLEXPART version 6.2, Atmos. Chem. Phys., 5(9), 2461-2474, doi:10.5194/acp-5-24612005.

Trenberth, K., and J. Fasullo (2012), Tracking earth's energy: From E1 Niño to global warming, Surv. Geophys., 33(3-4), 413-426, doi: 10.1007/s10712-011-9150-2.

Trenberth, K. E. (1997), The definition of El Niño, Bull. Am. Meteorol. Soc., 78(12), 2771-2777.

Trenberth, K. E., G. W. Branstator, D. Karoly, A. Kumar, N.-C. Lau, and C. Ropelewski (1998), Progress during TOGA in understanding and modeling global teleconnections associated with tropical sea surface temperatures, J. Geophys. Res., 103(C7), 14,291-14,324, doi:10.1029/ $97 \mathrm{jc} 01444$.

Trenberth, K. E., J. T. Fasullo, and J. Mackaro (2011), Atmospheric moisture transports from ocean to land and global energy flows in reanalyses, J. Clim., 24(18), 4907-4924, doi:10.1175/2011jcli4171.1.

Tuinenburg, O. A., R. W. A. Hutjes, C. M. J. Jacobs, and P. Kabat (2011), Diagnosis of local land-atmosphere feedbacks in India, J. Clim., 24(1), 251-266.

Tuinenburg, O. A., R. W. A. Hutjes, and P. Kabat (2012), The fate of evaporated water from the Ganges basin, J. Geophys. Res., 117(D1), D01107, doi:10.1029/2011jd016221.

van den Hurk, B., F. Doblas-Reyes, G. Balsamo, R. D. Koster, S. I. Seneviratne, and H. Camargo Jr. (2012), Soil moisture effects on seasonal temperature and precipitation forecast scores in Europe, Clim. Dyn., 38(12), 349-362, doi:10.1007/s00382-010-0956-2.

van den Hurk, B. J. J. M., and E. van Meijgaard (2009), Diagnosing landatmosphere interaction from a regional climate model simulation over 


\section{VAN DER ENT AND SAVENIJE: PRECIPITATION AND CORRELATION WITH SST}

West Africa, J. Hydrometeorol., 11(2), 467-481, doi:10.1175/ 2009jhm1173.1.

van der Ent, R., O. Tuinenburg, H.-R. Knoche, H. Kunstmann, and H. Savenije (2013), Should you use a simple or complex model moisture recycling and atmospheric water tracing?, Geophys. Res. Abstr., 15(EGU2013-2283-1), EGU General Assembly 2013 - Poster.

van der Ent, R. J., H. H. G. Savenije, B. Schaefli, and S. C. Steele-Dunne (2010), Origin and fate of atmospheric moisture over continents, Water Resour. Res., 46, W09525, doi:10.1029/2010WR009127.

van der Ent, R. J., and H. H. G. Savenije (2011), Length and time scales of atmospheric moisture recycling, Atmos. Chem. Phys., 11(5), 1853-1863, doi:10.5194/acp-11-1853-2011.

Vizy, E. K., and K. H. Cook (2002), Development and application of a mesoscale climate model for the tropics: Influence of sea surface temperature anomalies on the West African monsoon, J. Geophys. Res.-Atmos., 107(D3), ACL 2-1-ACL 2-22, doi:10.1029/2001jd000686.

Ward, P. J., W. Beets, L. M. Bouwer, J. C. J. H. Aerts, and H. Renssen (2010), Sensitivity of river discharge to ENSO, Geophys. Res. Lett., 37, L12402, doi:10.1029/2010g1043215.

Xie, S.-P., C. Deser, G. A. Vecchi, J. Ma, H. Teng, and A. T. Wittenberg (2010), Global warming pattern formation: Sea surface temperature and rainfall, J. Clim., 23(4), 966-986, doi:10.1175/2009jcli3329.1.

Yoshimura, K., T. Oki, N. Ohte, and S. Kanae (2003), A quantitative analysis of short-term O-18 variability with a Rayleigh-type isotope circulation model, J. Geophys. Res.-Atmos., 108(D20), 4647, doi:10.1029/ $2003 j \mathrm{j} 003477$.

Yoshimura, K., T. Oki, N. Ohte, and S. Kanae (2004), Colored moisture analysis estimates of variations in 1998 Asian monsoon water sources, $J$. Meteorol. Soc. Jpn., 82(5), 1315-1329, doi:10.2151/jmsj.2004.1315. 